\title{
FUNGAL AGENTS IN DIFFERENT ANATOMICAL SITES IN PUBLIC HEALTH SERVICES IN CUIABÁ, STATE OF MATO GROSSO, BRAZIL
}

\author{
Sebastião Martins de ARAÚJO(1), Cor Jésus Fernandes FONTES(1), Diniz Pereira LEITE JÚNIOR(1) \& Rosane Christine HAHN(1)
}

\begin{abstract}
SUMMARY
Introduction: A contribution to the regional epidemiological profile of the most common fungal agents in Public Health Services in Cuiabá, state of Mato Grosso, including university hospitals and polyclinics. Methods: Clinical specimens $(\mathrm{n}=1,496)$ from 1,078 patients were collected, submitted to direct mycological exam (potash or stick tape method) and cultured in specific mediums. Dermatophytic and non-dermatophytic agents were identified according to micromorphology (Ridell technique). Results: The majority of the 1,496 specimens were skin $(n=985)$ and nail exams $(n=472)$. Of the 800 positive cultures, $246(30.8 \%)$ corresponded to dermatophytes and $336(42 \%)$ to yeasts of the genus Candida, 190 (23.7\%) to other yeasts, 27 (3.4\%) to non-dermatophytic filamentous fungi and one $(0.1 \%)$ the agent of subcutaneous mycosis. Lesions considered primary occurred in greater numbers $(59.5 \%)$ than recurrent lesions $(37.4 \%)$, with a greater concentration of positivity occurring on the arms and legs. Conclusions: Comorbidities, allergies and diabetes mellitus were conditions associated with greater positivity in direct mycological exams and cultures. Positive culture was considered a definitive diagnosis of fungal infection and confirmed $47.8 \%$ of diagnostic hypotheses.
\end{abstract}

KEYWORDS: Dermatomycoses; Fungal agents; Mato Grosso.

\section{INTRODUCTION}

In dermatology out-patient clinics, principally in tropical countries, cases of tineas (cutaneous/skin mycoses) and other superficial fungal infections presenting highly characteristic clinical aspects are observed daily, definitively favoring their diagnoses. Several factors affect the higher incidence of superficial and cutaneous mycoses, including: bioclimatic conditions favorable to the development of fungi in saprophytic life; promiscuity; sweating; prolonged contact with pets (cats and dogs), since they constitute potential reservoirs of certain dermatophytes; and contaminated water from swimming pools and surrounding risk areas (paving close to pools) ${ }^{24}$.

Superficial and cutaneous mycoses can be detected on the skin, in hair, on the nails, in periungual folds, in the mucosa and cutaneomucosal zones. It is not possible to outline an exact profile of the epidemiology of superficial and cutaneous mycoses, because they are not diseases that require compulsory notification. Certain tineas are extremely contagious, provoking microepidemics in schools or micro-epizootics, the latter especially among captive animals (rabbits, guinea pigs, mice and rats), though they also occur in rural areas and occasionally do not provoke obvious clinical lesions ${ }^{42,44,45}$.

Epidemiological studies in Brazil have demonstrated the distribution of etiological agents responsible for superficial and cutaneous fungal infections in several geographical regions. The literature contains data collected and analyzed from the states of São Paulo ${ }^{9}$, Goiás ${ }^{12}$, Rio Grande do Sul ${ }^{3}$, Santa Catarina ${ }^{47}$, Minas Gerais ${ }^{30}$, Distrito Federal ${ }^{8}$, Amazonas ${ }^{16}$, Paraná ${ }^{40}$ and Ceará 6 .

However, our review found no record of any kind of study conducted in the state of Mato Grosso, despite the fact that the bioclimatic conditions are extremely favorable to the appearance of such fungal infections. Thus, this work aimed to contribute to current understanding regarding the etiological distribution of the most frequent fungal agents detected in the primary healthcare service of the Brazilian National Health System (Sistema Único de Saúde, SUS) in Cuiabá, MT, elucidating the demographic, clinical and laboratorial aspects in order to permit the institution of early, effective therapy.

\section{MATERIAL AND METHODS}

Casuistic: Between March 2006 and December 2010, 1,496 clinical specimens were collected from 1,078 patients with lesions located in different anatomical sites, who were attended to at the SUS polyclinics and university hospitals in Cuiabá, state of Mato Grosso. This study was approved by the Ethics in Research Committee of Hospital Universitário Julio Muller under protocol number 240/06 - CEP/HUJM.

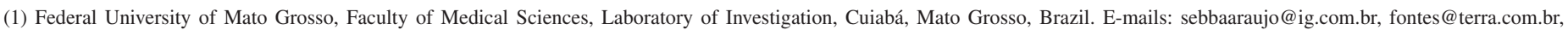
djbiologico@gmail.com,rchahn@terra.com.br,

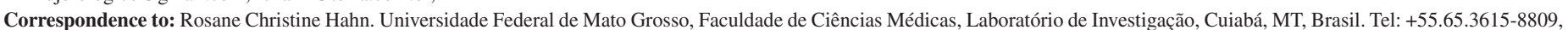
Fax: +55.65.3615-8856. E-mail: rchahn@ terra.com.br.

Financial Support: FAPEMAT/PPSUS. 
ARAÚJO, S.M.; FONTES, C.J.F.; LEITE JÚNIOR, D.P. \& HAHN, R.C. - Fungal agents in different anatomical sites in Public Health Services in Cuiabá, state of Mato Grosso, Brazil. Rev. Inst. Med. Trop. Sao Paulo, 54(1): 5-10, 2012.

Demographic and clinical data and predisposing factors: Patient demographic data, including age, sex and place of residence, were registered in individual patient forms, together with clinical data regarding lesion time (months), category, lesion site and appearance, and predisposing factors, such as contact with animals, superficial traumas, comorbidities and prior use of medications, and later evaluated.

Clinical specimens examined: Samples of skin, hair, mucous and nails from patients with suspected dermatomycoses were collected by scraping the surfaces with sterile scalpel blades. From the scalp, cutaneous exfoliation and damaged hairs were removed with sterile tweezers. The materials collected were placed in previously labelled sterile petri-dishes.

Direct mycological examination: Direct mycological examination (DME) was performed using $20 \% \mathrm{KOH}$ on skins flakes and $40 \% \mathrm{KOH}$ on hair and nails to gently dissolve the clinical material in order to improve visualization of the fungal parasite. Exams performed by the adhesive-tape method were used on patients presenting non-flaking or minimally flaking lesions ${ }^{23,24,49}$.

Culture isolation: Isolation of the primary fungus was performed simultaneously with direct microscopy in specific culture media: Sabouraud dextrose agar (DIFCO) with added chloramphenicol and Mycobiotic agar (DIFCO). The samples were incubated at $27{ }^{\circ} \mathrm{C}$ for seven to 20 days and observed daily ${ }^{23,24,49}$.

Use of chromogenic agar: Chromogenic CHROMagar medium (BBL) was only used to determine the purity of the isolated colonies suggestive of the genus Candida. To identify the yeast species, the classic methodology was used, including the following tests: germinative tube; zymogram, carbohydrate fermentation; auxanogram, carbohydrate assimilation; and the Ridell Technique, microculture ${ }^{23,24,49}$.

Identification of mycelial fungi: Identification of the groups of dermatophytic and filamentous fungi was achieved by observation of the macro- and micro-morphological characteristics (the Ridell Technique) of the developed colonies and, in specific cases, by biochemical tests ${ }^{23,24,49}$.

\section{RESULTS}

Of the 1,078 patients evaluated, 642 (59.6\%) were women and 436 (40.4\%) were men, with an age range from six months to 96 years old and a mean (standard deviation) of 38.8 (19.6) years-old. The majority of the patients $(68 \%)$ were resident in the state of Mato Grosso and another $13.6 \%$ were resident in other states of the central-western region. Residents from the northern region contributed to the lowest proportion of cases $(1.5 \%)$. An important portion of patients were concentrated in the age groups of 20 to 49 years old $(53.2 \%)$ and 50 years old or over $(32.4 \%)$. In contrast, the 1- to 9-year-old age group presented the lowest proportion of patients $(3.8 \%)$.

For the mycological investigation, 1,496 clinical samples were collected, comprising skin flakes $(65.8 \%)$, nail fragments $(31.6 \%)$, mucous $(1.8 \%)$, secretion $(0.3 \%)$ and hairs $(0.5 \%)$. The main cutaneous sites $(\mathrm{n}=725)$ with suspected dermatomycosis lesions were the legs $(21.2 \%)$, arms $(16.1 \%)$ and thorax $(15.8 \%)$. Among the phaneros $(\mathrm{n}=$ 428), the nails were by far the most commonly affected sites $(98.1 \%)$
(Table 1). The disease period reported by the patients varied from one month to 40 years, with a median (Q1 to Q3) of 12 months (2 - 48 months). The majority of patients $(48.1 \%)$ reported lesion times of more than six

Table 1

Clinical characteristics of the 1,078 patients with suspected fungal infections attended by the primary healthcare service of the Brazilian National Health Service (SUS), Cuiabá, MT, 2006-2010

\begin{tabular}{|c|c|c|c|}
\hline Characteristic & & $\mathrm{n}$ & $\%$ \\
\hline \multirow[t]{5}{*}{ Clinical specimen } & Skin & 725 & 61.2 \\
\hline & Nails & 420 & 35.5 \\
\hline & Mucous & 27 & 2.3 \\
\hline & Hair & 8 & 0.7 \\
\hline & Secretion & 4 & 0.3 \\
\hline \multirow[t]{18}{*}{ Lesion site } & $\underline{\text { Skin }}$ & & \\
\hline & Legs & 154 & 21.2 \\
\hline & Arms & 117 & 16.1 \\
\hline & Thorax & 115 & 15.8 \\
\hline & Face & 47 & 6.5 \\
\hline & Scalp & 39 & 5.4 \\
\hline & Buttock & 36 & 5.0 \\
\hline & Breast & 7 & 1.0 \\
\hline & Ear & 6 & 0.8 \\
\hline & Axilla & 11 & 1.5 \\
\hline & Genital region & 7 & 0.8 \\
\hline & Inguinal region & 13 & 1.8 \\
\hline & Feet & 89 & 12.3 \\
\hline & Hands & 36 & 5.0 \\
\hline & Other regions & 50 & 6.8 \\
\hline & $\underline{\text { Phaneros }}$ & & \\
\hline & Nails & 420 & 98.1 \\
\hline & Hair & 8 & 1.9 \\
\hline \multirow{5}{*}{$\begin{array}{l}\text { Lesion time } \\
\text { (months) }\end{array}$} & $<1$ & 118 & 10.0 \\
\hline & $1-3$ & 265 & 22.4 \\
\hline & $3-6$ & 189 & 16.0 \\
\hline & $>6$ & 570 & 48.1 \\
\hline & not reported & 42 & 3.5 \\
\hline \multirow{8}{*}{$\begin{array}{l}\text { Lesion clinical } \\
\text { aspect* }\end{array}$} & Cutaneous exfoliation & 451 & 38.1 \\
\hline & Opaque/brittle nail & 384 & 32.4 \\
\hline & Cutaneous ulcer & 73 & 6.2 \\
\hline & Cutaneous scab & 61 & 5.2 \\
\hline & Cutaneous hypochromia & 73 & 6.2 \\
\hline & Cutaneous blister & 19 & 1.6 \\
\hline & Cutaneous nodule & 6 & 0.5 \\
\hline & Not reported & 117 & 9.9 \\
\hline \multirow{3}{*}{$\begin{array}{l}\text { Lesion evolutive } \\
\text { category }\end{array}$} & Primary & 705 & 59.5 \\
\hline & Recurrent & 443 & 37.4 \\
\hline & Not reported & 36 & 3.0 \\
\hline
\end{tabular}

*: exfoliation, itching and erythema were present in the lesions of clinical specimens 1093, 830 and 641, respectively. 


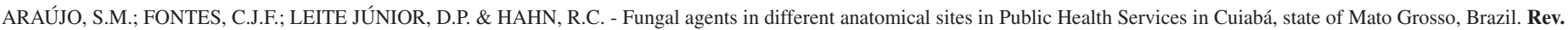
Inst. Med. Trop. Sao Paulo, 54(1): 5-10, 2012

months duration. The types of lesions were presented in the following proportions: cutaneous exfoliation $(38.1 \%)$, opaque/brittle nails $(32.4 \%)$, cutaneous ulcerations $(6.2 \%)$ and cutaneous scabs $(5.2 \%)$. The triad that characterizes dermatophytoses; i.e. flaking, itching and erythema, were observed in the majority of lesions and were present in lesions 1093, 830 and 641 , respectively. Primary lesions predominated (59.5\%), with only $37.4 \%$ of patients presenting recurrent lesions (Table 1).

Table 2 presents the likely predisposing factors for fungal infection in suspected lesions observed in patients attended by the primary healthcare service of the SUS, Cuiabá, MT, in the period from 2006 to 2010. Diabetes mellitus (6.0\%) and allergies (3.7\%) were the most frequent comorbidities reported by the patients in the study. Dogs were the most commonly reported pet / domestic animal (42.5\%), followed by cats $(14.3 \%)$. Prior history of superficial trauma was denied by the majority of patients $(90.4 \%)$.

Table 3 presents the frequency of fungal genera and species identified in superficial, cutaneous and subcutaneous lesions of patients attended by the primary healthcare service of the SUS, Cuiabá, MT, in the period from 2006 to 2010. Observation verified the predominance of yeasts

\section{Table 2}

Probable predisposing factors for 1,078 fungal infections in suspected lesions attended to by the primary healthcare service of the Brazilian National Health Service (SUS), Cuiabá, MT, 2006-2010

\begin{tabular}{|c|c|c|c|}
\hline \multirow{3}{*}{$\begin{array}{l}\text { Factor } \\
\text { Contact with } \\
\text { animals }\end{array}$} & & \multirow{2}{*}{$\frac{\mathrm{n}}{458}$} & \multirow{2}{*}{$\frac{\%}{42.5}$} \\
\hline & Dogs & & \\
\hline & Cats & 154 & 14.3 \\
\hline & Pet birds & 32 & 3.0 \\
\hline & Other domestic animals & 30 & 2.8 \\
\hline & Other sources of contamination & 404 & 37.5 \\
\hline \multirow{8}{*}{$\begin{array}{l}\text { Previously } \\
\text { reported } \\
\text { trauma }\end{array}$} & Contusions & 30 & 2.8 \\
\hline & Punctures & 14 & 1.3 \\
\hline & Abrasions & 16 & 1.5 \\
\hline & Surgery & 5 & 0.5 \\
\hline & Cuts & 14 & 1.3 \\
\hline & Prolonged pressure & 13 & 1.2 \\
\hline & Others & 12 & 1.1 \\
\hline & None & 974 & 90.4 \\
\hline \multirow{6}{*}{$\begin{array}{l}\text { Prior use of } \\
\text { medications }\end{array}$} & Antifungal drugs & 136 & 12.6 \\
\hline & Corticosteroids & 48 & 4.5 \\
\hline & Antibiotics & 38 & 3.5 \\
\hline & Home-made remedies & 7 & 0.6 \\
\hline & Others & 156 & 14.5 \\
\hline & None & 693 & 64.3 \\
\hline \multirow{7}{*}{$\begin{array}{l}\text { Reported } \\
\text { comorbidity }\end{array}$} & Diabetes mellitus & 65 & 6.0 \\
\hline & Allergy & 40 & 3.7 \\
\hline & AIDS & 23 & 2.1 \\
\hline & Lupus erythematosus & 11 & 1.0 \\
\hline & Hypothyroidism & 4 & 0.4 \\
\hline & Others & 85 & 7.9 \\
\hline & None & 850 & 78.8 \\
\hline
\end{tabular}

of the genus Malassezia 176 (22\%) in skin lesions, indicating a high frequency of cases of pityriasis versicolor in the population evaluated. In relation to hair clinical material, only five species were isolated: two cases of Trichophyton tonsurans, Trichosporon cutaneum and other Microsporum canis. We performed 16 collections relating to mucous and secretion, resulting in isolation of Candida albicans 15 (93.8\%) and Candida parapsilosis one (6.3\%). In skin lesions, T. rubrum corresponded to $101(20.3 \%)$ of the isolates and T. mentagrophytes to 37 (7.4\%); these constituted the majority of the dermatophytes identified.

\section{DISCUSSION}

A series of studies conducted in Brazil since the 1960s indicates the distribution of causative agents of superficial mycoses and dermatophytic agents in numerous cities and Brazilian regions $^{3,6,8,10,12-14,19,26,27,30,32,39,40,43,46-48,51,54}$. The reports of fungal infections and their agents in populations in world, have been addressed by several authors ${ }^{2,15,21,22,29,31,52,58}$.

Dermatophytes are known to grow best in warm and humid environments and are, therefore, more common in tropical and subtropical regions. Some species for dermatophytes such as Trichophyton mentagrophytes var. interdigitale, Microsporum canis, Epidermophyton floccosum and Trichophyton rubrum are relatively common in several regions of the globe. Other species have partial geographic restriction; for example, Trichophyton violaceum is found in Asia, Africa and Europe; Trichophyton concentricum in the India and the Pacifics ${ }^{2}$ and Trichophyton schoenleinii and Trichophyton soudanense is restricted to Africa ${ }^{53}$. In this study the species reported predominantly in the central western part of Brazil that are distributed all over the world were: Trichophyton rubrum, Trichophyton mentagrophytes; Trichophyton verrucosum, Trichophyton tonsurans, Microsporum canis and Microsporum gypseum. Among the yeasts, we can highlight Candida albicans, Candida parapsilosis and Malassezia spp., which have also been isolated as agents of superficial and cutaneous mycoses.

In recent times, infections caused by dermatophytes have assumed greater significance. The increasing number of patients with immunocompromised states, such as AIDS, diabetes mellitus, lupus, allergy, cancer and organ transplantation, has given these infections more prominence $\mathrm{e}^{5,18,20,28,37,38,56}$. Reports of infections by non-dermatophytes has also received greater attention ${ }^{4,7,34,51}$. In this study, Diabetes mellitus $(6.0 \%)$ and allergies $(3.7 \%)$ were observed in patients. These were the most frequent comorbidities reported by the patients.

Regarding skin and nail dermatophytes, mycotic lesions are less frequent among children, who present fewer keratinized sites than adults ${ }^{41}$. Onychomycosis is more common in diabetic patients than in non-diabetic patients. It is more than a cosmetic problem, and diabetic patients have a greater risk of serious complications with the disease $\mathrm{e}^{55}$. The predominance of women among individuals with superficial and cutaneous fungal infections has been reported by other authors ${ }^{4,14,34,36,57}$, who proposed the hypothesis that clinical manifestations of certain dermatomycoses (e.g. in nails) could be predominantly cosmetic and affect women more directly than men.

Among the group of superficial and cutaneous fungal infections, candidiasis should be highlighted. Onychomycosis of fingernails is most 
ARAÚJO, S.M.; FONTES, C.J.F.; LEITE JÚNIOR, D.P. \& HAHN, R.C. - Fungal agents in different anatomical sites in Public Health Services in Cuiabá, state of Mato Grosso, Brazil. Rev. Inst. Med. Trop. Sao Paulo, 54(1): 5-10, 2012.

Table 3

Frequency of fungal genera and species $(\mathrm{n}=800)$ identified and diagnosed in patients attended by the primary healthcare service of the Brazilian National Health Service (SUS), Cuiabá, MT, 2006-2010.

\begin{tabular}{|c|c|c|c|}
\hline $\begin{array}{l}\text { Clinical } \\
\text { specimen }\end{array}$ & Genus/species & $\mathrm{n}$ & $\%$ \\
\hline \multirow{24}{*}{$\begin{array}{l}\text { SKIN } \\
(n=498)\end{array}$} & Malassezia spp. & 176 & 35.3 \\
\hline & Trichophyton rubrum & 101 & 20.3 \\
\hline & Candida parapsilosis & 77 & 15.5 \\
\hline & Trichophyton mentagrophytes & 37 & 7.4 \\
\hline & Candida albicans & 22 & 4.4 \\
\hline & Microsporum canis & 16 & 3.2 \\
\hline & Candida tropicalis & 15 & 3.0 \\
\hline & Epidermophyton floccosum & 12 & 2.4 \\
\hline & Microsporum gypseum & 8 & 1.6 \\
\hline & Trichosporon spp. & 5 & 1.0 \\
\hline & Candida guilliermondii & 4 & 0.8 \\
\hline & Trichophyton tonsurans & 3 & 0.6 \\
\hline & Trichophyton violaceum & 3 & 0.6 \\
\hline & Candida famata & 3 & 0.6 \\
\hline & Candida kefyr & 3 & 0.6 \\
\hline & Candida lusitaniae & 2 & 0.4 \\
\hline & Candida lipolytica & 2 & 0.4 \\
\hline & Trichophyton verrucosum & 2 & 0.4 \\
\hline & Candida glabrata & 2 & 0.4 \\
\hline & Candida sp. & 1 & 0.2 \\
\hline & Exophiala werneckii & 1 & 0.2 \\
\hline & Trichophyton interdigitali & 1 & 0.2 \\
\hline & Sporothrix schenckii & 1 & 0.2 \\
\hline & Candida rugosa & 1 & 0.2 \\
\hline \multirow{8}{*}{$\begin{array}{l}\text { TOENAILS } \\
(n=166)\end{array}$} & Candida parapsilosis & 65 & 39.2 \\
\hline & Trichophyton rubrum & 28 & 16.9 \\
\hline & Trichophyton mentagrophytes & 14 & 8.4 \\
\hline & Fusarium spp. & 16 & 9.6 \\
\hline & Candida albicans & 10 & 6.0 \\
\hline & Scopulariopsis brevicaulis & 6 & 3.6 \\
\hline & Candida tropicalis & 6 & 3.6 \\
\hline & Trichosporon spp. & 4 & 2.4 \\
\hline
\end{tabular}

prevalent in females while toenail infection is common in male patients ${ }^{1,57}$. Candida species is the dominant cause of onychomycosis in women and dermatophytes is the principal cause of this condition in men ${ }^{35,51}$. According to CROCCO et al. ${ }^{13}$, candidiasis expresses the variety of relations that occur between the host and autochthon microbiota, ranging from commensalism to systemic disease. Different groups of previously used medications can contribute to the appearance of superficial and systemic fungal infections by yeasts of the genus Candida ${ }^{11}$. In this study, antifungal drugs were reported by $12.6 \%$ of patients, followed by corticosteroids (4.5\%) and antibiotics (3.5\%).

Causative agents of dermatomycoses were isolated from $47.8 \%$ of the samples cultured for fungi. These cultures were interpreted as proof

\begin{tabular}{|c|c|c|c|}
\hline $\begin{array}{l}\text { Clinical } \\
\text { specimen }\end{array}$ & Genus/species & $\mathrm{n}$ & $\%$ \\
\hline \multirow{11}{*}{$\begin{array}{l}\text { TOENAILS } \\
(\mathrm{n}=166)\end{array}$} & Candida kefyr & 3 & 1.8 \\
\hline & Trichophyton tonsurans & 2 & 1.2 \\
\hline & Scytalidium dimidiatum & 2 & 1.2 \\
\hline & Candida guilliermondii & 2 & 1.2 \\
\hline & Trichophyton verrucosum & 2 & 1.2 \\
\hline & Candida famata & 1 & 0.6 \\
\hline & Candida rugosa & 1 & 0.6 \\
\hline & Candida lusitaniae & 1 & 0.6 \\
\hline & Trichophyton interdigitali & 1 & 0.6 \\
\hline & Candida glabrata & 1 & 0.6 \\
\hline & Candida krusei & 1 & 0.6 \\
\hline \multirow{13}{*}{$\begin{array}{l}\text { FINGERNAIL } \\
(\mathbf{n}=112)\end{array}$} & Candida parapsilosis & 53 & 47.3 \\
\hline & Candida albicans & 16 & 14.3 \\
\hline & Candida tropicalis & 15 & 13.4 \\
\hline & Trichophyton rubrum & 7 & 6.3 \\
\hline & Trichophyton mentagrophytes & 6 & 5.4 \\
\hline & Candida glabrata & 3 & 2.7 \\
\hline & Fusarium spp. & 3 & 2.7 \\
\hline & Candida guilliermondii & 2 & 1.8 \\
\hline & Candida lusitaniae & 2 & 1.8 \\
\hline & Trichosporon spp. & 2 & 1.8 \\
\hline & Candida famata & 1 & 0.9 \\
\hline & Candida krusei & 1 & 0.9 \\
\hline & Candida viswanathii & 1 & 0.9 \\
\hline \multirow{3}{*}{$\begin{array}{l}\text { HAIR } \\
(n=5)\end{array}$} & Trichophyton tonsurans & 2 & 40.0 \\
\hline & Trichosporon cutaneum & 2 & 40.0 \\
\hline & Microsporum canis & 1 & 20.0 \\
\hline \multirow{2}{*}{$\begin{array}{l}\text { MUCOUS } \\
(\mathrm{n}=16)\end{array}$} & Candida albicans & 15 & 93.8 \\
\hline & Candida parapsilosis & 1 & 6.2 \\
\hline \multirow{2}{*}{$\begin{array}{l}\text { SECRETION } \\
(\mathbf{n}=\mathbf{3})\end{array}$} & Candida albicans & 2 & 66.7 \\
\hline & Candida parapsilosis & 1 & 33.3 \\
\hline
\end{tabular}

of the diagnostic hypothesis of mycosis. Verification of $47.8 \%$ of positive cultures is in agreement with the range of positivity that has been reported in the literature for these types of mycoses, which vary between $20.8 \%$ and $60 \%$, when culture is considered a diagnostic criterion ${ }^{40,50}$. Several causes have been indicated to justify the low rate of fungi recovery in culture media, as registered in this study. Among these, two should be highlighted: prior use of medication, a factor frequently underreported by patients; and equivocal clinical diagnosis, related to the existence of numerous skin lesions and attachments that are clinically similar to mycoses, though with distinct etiologies ${ }^{33}$.

In the state of Paraná, six cases of Tinea nigra were reported in 2003 , corresponding to cases diagnosed between 1978 and $2001^{17}$. This small 
ARAÚJO, S.M.; FONTES, C.J.F.; LEITE JÚNIOR, D.P. \& HAHN, R.C. - Fungal agents in different anatomical sites in Public Health Services in Cuiabá, state of Mato Grosso, Brazil. Rev. Inst. Med. Trop. Sao Paulo, 54(1): 5-10, 2012.

casuistic corroborates the infrequent character or subdiagnosis of this fungal infection. In toenail lesions, the following species were the most frequent: 28 isolates of T. rubrum (16.9\%) and 14 of T. mentagrophytes $(8.4 \%)$, contrasting with the lower rate of isolation in fingernails, seven isolates of T. rubrum (6.3\%) and six of T. mentagrophytes (5.4\%).

Regarding nail lesions (fingers and toes), it can be inferred that the extreme adaptation achieved by these microorganisms in relation to the human host, together with the chronicity so frequently associated with lesions involving these sites, permit the novel hypothesis that the low rate of culture positivity could be due to the inability to grow in vitro microorganisms so well adapted to human tissue for such a long period of time. LEYDEN (1994) ${ }^{25}$ further suggests, specifically regarding Tinea pedis, that the presence of maceration implies the establishment of secondary bacterial infection.

In conclusion, yeasts of the genus Candida predominate dermatophytes as agents of dermatomycoses at all the sites evaluated, except on hairs. The high frequency of these yeasts on nails can be attributed to the significant isolation of Candida parapsilosis, which is a component of the microbiota of this anatomic site. Among the dermatophytes, $T$. rubrum and T. mentagrophytes were the most frequently identified agents of suspected dermatomycosis lesions. Finally, it should be highlighted that resistance to antifungal drugs is growing and is one of the reasons that characterization of the etiological agent at the level of genus and species has been indicated as an important support for the choice of therapeutic management.

\section{RESUMO}

\section{Agentes fúngicos em diferentes sítios anatômicos nos Serviços de Saúde Pública em Cuiabá, Mato Grosso, Brasil}

Introdução: Contribuição sobre o perfil epidemiológico regional referente aos agentes fúngicos mais freqüentes nos Serviços de Saúde Pública em Cuiabá-MT, incluindo policlínicas e hospitais universitários. Métodos: Foram examinados 1.496 espécimes clínicos colhidos a partir de 1.078 pacientes, os quais foram submetidos ao exame direto (potassa e/ou fita gomada) e cultivos em meios específicos. Os agentes foram identificados segundo micromorfologia (técnica de Ridell). Resultados: Os 1.496 espécimes foram relacionados na maioria a exames de pele ( $\mathrm{n}=985)$, e unhas $(\mathrm{n}=472)$. Dos 800 cultivos positivos, $246(30,8 \%)$ corresponderam a dermatófitos, $336(42 \%)$ a leveduras do gênero Candida, $190(23,7 \%)$ a outras leveduras, $27(3,4 \%)$ a fungos filamentosos não dermatofíticos e um $(0,1 \%)$ a agente de micoses subcutâneas. Lesões consideradas primárias compareceram em maior número $(59,5 \%)$, comparadas as recidivantes $(37,4 \%)$. Foi observada maior positividade em membros inferiores e superiores. Conclusões: Co-morbidades, quadros alérgicos e diabetes mellitus representaram condições associadas à maior positividade em exames micológicos diretos e cultivos. $\mathrm{O}$ cultivo positivo foi considerado como diagnóstico definitivo de infecção fúngica, e confirmou $47,8 \%$ de hipóteses diagnósticas.

\section{ACKNOWLEDGEMENTS}

Financial Support: FAPEMAT/PPSUS.

\section{REFERENCES}

1. Aghamirian MR \& Ghiasian SA. Onychomycosis in Iran: epidemiology, causative agents and clinical features. Nihon Ishinkin Gakkai Zasshi. 2010;51:23-9.

2. Ameen, M. Epidemiology of superficial fungal infection. Clin Dermatol. 2010;28:197201.

3. Aquino VR, Constante CC, Bakos L. Frequência das dermatofitoses em exames micológicos em Hospital Geral de Porto Alegre, Brasil. An Bras Dermatol. 2007;82:239-44

4. Bakheshwain S, El Khizzi N, Al Rasheed AM, Al Ajlan A, Parvez S. Isolation of opportunistc fungi from dermatophytic samples. Asian J Dermatol. 2011;3:13-9.

5. Berg JC, Hamacher KL, Roberts GD. Pseudomycetoma caused by Microsporum canis in a immunosuppressed patient: a case report and review of the literature. J Cutan Pathol. 2007;34:431-4.

6. Brilhante RSN, Paixão GC, Salvino LK, Diógenes MJN, Bandeira SP, Rocha MFG, et al. Epidemiologia e ecologia das dermatofitoses na cidade de Fortaleza: o Trichophyton tonsurans como importante patógeno emergente da Tinea capitis. Rev Soc Bras Med Trop. 2000;33:417-25.

7. Calado NB, Souza F Jr, Gomes NO, Cardoso FR, Zaror LC, Milan EP. Fusarium nail and skin infection: a report of eight cases from Natal, Brazil. Mycopathologia. 2006; $161: 27-31$

8. Campbell I, Campbell G, Aguirre L, Santos MG. Dermatófitos em Brasília. An Bras Dermatol. 1984;59:224-5.

9. Chinelli PAV, Sofiatti AA, Nunes RS, Martins JEC. Dermatophytes agents in the city of São Paulo, from 1992 to 2002. Rev Inst Med Trop Sao Paulo. 2003;45:259-63.

10. Coelho MPP, Mendes BG, Soprana HZ, Santo LFV, Nappi BP, Santos JI. Micoses observadas em pacientes atendidos no Hospital Universitário, Florianópolis, Santa Catarina. Rev Bras Anal Clin. 2005;37:27-30.

11. Colombo AL, Guimarães T. Epidemiologia das infecções hematogênicas por Candida spp. Rev Soc Bras Med Trop. 2003;36:599-607.

12. Costa M, Passos XS, Souza LKH, Miranda ATB, Lemos JA, Oliveira Jr JG, et al Epidemiologia e etiologia das dermatofitoses em Goiânia, GO, Brasil. Rev Soc Bras Med Trop; 2002;35:19-22.

13. Crocco EI, Mimica LMJ, Muramatu LH, Garcia C, Souza VM, Ruiz LRB, et al. Identificação de espécies de Candida e susceptibilidade antifúngica in vitro: estudo de 100 pacientes com candidíases superficiais. An Bras Dermatol. 2004;79:689-97.

14. Damázio PMR, Lacerda HR, Lacerda Filho AM, Magalhães OMC, Neves, RP. Epidemiologia, etiologia e formas clínicas das dermatofitoses em Pernambuco, 1995-2005. Rev Soc Bras Med Trop. 2007;40:484-6.

15. Falahati M, Akhlaghi L, Lari AR, Alaghehbandan R. Epidemiology of dermatophytoses in an area south of Tehran, Iran. Mycopathologia. 2003;156:279-87.

16. Furtado MSS, Ihara LT, Maroja MF, José JIN, Castrillón AL. Dermatofitose na cidade de Manaus - AM. An Bras Dermatol. 1987;62:195-6.

17. Giraldi S, Marinoni LP, Bertogna J, Abbage KT, Oliveira VC. Tinea nigra: relato de seis casos no estado do Paraná. An Bras Dermatol. 2003;78:593-600.

18. Gomides MDA,Berbert ALC, Manteses SAO, Rocha A, Ferreira MS, Borges AS. Dermatoses em pacientes com AIDS: estudo de 55 casos. Uberlância. MG, Brasil Rev Assoc Med Bras. 2002;48:36-41.

19. Gürtler TGR, Diniz LM, Nicchio L. Microepidemia de tinha do couro cabeludo por Microsporum canis em creche de Vitória-Espirito Santo (Brasil). An Bras Dermatol. 2005;80:267-72. 
ARAÚJO, S.M.; FONTES, C.J.F.; LEITE JÚNIOR, D.P. \& HAHN, R.C. - Fungal agents in different anatomical sites in Public Health Services in Cuiabá, state of Mato Grosso, Brazil. Rev. Inst. Med. Trop. Sao Paulo, 54(1): 5-10, 2012.

20. Havlickova B, Czaika VA, Friedrich M. Epidemiological trends in skin mycoses worldwide. Mycoses. 2008;51(Suppl 4):2-15.

21. Kaur R, Kashyap B, Bhalla P. Onychomycosis - epidemiology, diagnosis and management. Indian J Med Microbiol. 2008;26:108-16.

22. Kheira H, Selselet AG, Bensoltane SA. Dermatophytes in North West of Algeria: a prospective study. Middle-East J Sci Res. 2007;2:104-6.

23. Kwong-Chung KJ, Bennet JE. Candidiasis. In: Kwong-Chung KJ, Bennet JE. Medical Mycology. Philadelphia: Lea \& Febiger; 1992. p. 280-336.

24. Lacaz CS, Porto E, Martins JEC, Heins-Vaccari EM, Mello NT. Tratado de Micologia médica Lacaz. 9. ed. São Paulo: Sarvier; 2002.

25. Leyden JL. Tinea pedis pathophysiology and treatment. J Am Acad Dermatol. 1994;31:S31-3

26. Lima EO, Pontes ZBV, Oliveira NMC, Carvalho MFF, Guerra MFL, Santos JPS. Frequiência de dermatofitoses em João Pessoa, Paraíba, Brasil. An Bras Dermatol. 1999;74:127-32.

27. Lopes JO, Alves SH, Mari CRD, Oliveira LTO, Brum LLM, Westphalen JB, et al. A ten-year survey of Tinea pedis in the central region of the Rio Grande do Sul, Brasil. Rev Inst Med Trop São Paulo. 1999;41:75-7.

28. Macedo DPC; Neves RP, Lopes FC. Case report: disseminated dermatophytosis by Microsporum gypseum in a systemic lupus erythematosus patient. Braz J Microbiol. 2008;39:25-7.

29. Mahmoudabadi AZ; Yaghoobi R; Owrak A. Cutaneous mycosis in a rural area of Ahvaz, Iran. Jundishapur J Microbiol. 2010;3:133-5.

30. Marchi MS, Carvalho MT, Pereira CAC, Modesto B. Incidência de dermatófitos em Juiz de Fora, Minas Gerais. An Bras Dermatol. 1983;58 253-6.

31. Marchisio VF, Preve L, Tullio V. Fungi responsible for skin mycoses in Turin (Italy). Mycoses. 1996;39:141-50.

32. Marques AS, Camargo RMP, Fares AHG, Takashi RM, Stolf HO. Tinea capitis: epidemiologia e ecologia dos casos observados entre 1983 e 2003 na Faculdade de Medicina de Botucatu, Estado de São Paulo, Brasil. An Bras Dermatol. 2005;80:597602

33. Mazón A, Salvo S, Vives R, Valcayo A, Sabalza MA. Estúdio etiológico y epidemiológico de las dermatofitosis en Navarra (Espanã). Rev Iberoam Micol. 1997;14:65-8.

34. Mbata TI. Dermatophytes and other skin mycoses found in featherless broiler toe webs. Internet J Dermatol. 2009;7(2)

35. Mercantini R, Marsella R, Moretto D. Onychomycosis in Rome, Italy. Mycopathologia. 1996;136:25-32.

36. Minelli LD, Minelli L. Micoses superficiais. Como diagnosticar e tratar. Rev Bras Med. $1991 ; 48: 57-63$

37. Nir-Paz R, Elinav H, Pierad E, Walker D, Maly A, Shapiro M, et al. Deep infection by Trichophyton rubrum in a immunocompromised patient. J Clin Microbiol. 2003;41:5298-301.

38. Nweze, EI. Dermatophytosis in western Africa: a review. Pakistan J Bio Sci. 2010;13;64956.

39. Oliveira JAA, Cortez ACA, Barros JA, Oliveira JSR. Micoses superficiais na cidade de Manaus, (AM), entre março e novembro/2003. An Bras Dermatol. 2006;81:238-43.

40. Perón, MLDF; Teixeira, JJV; Svidzinski, TIE. Epidemiologia e etiologia das dermatomicoses superficiais e cutâneas na região de Paranavaí, Paraná, Brasil. Rev Bras Anal Clín. 2005;37:77-81.
41. Perret MP, Mello MGM, Oliveira JMPC, Pereira RFB, Assis TL, Azulay RD. Inquérito epidemiológico das dermatoses na população escolar de 4 a 18 anos nas Ilhas do Governador e do Fundão. An Bras Dermatol. 1991;66:71-4.

42. Pinheiro AQ, Moreira JLB, Sidrim JJC. Dermatofitoses no meio urbano e a coexistência do homem com cães e gatos. Rev Soc Bras Med Trop. 1997;30:287-94.

43. Pozzi AC, Guilhermetti E, Kioshima ES, Pedra MR, Svidzinski TIE. Tinea capitis em Maringá, Paraná: um estudo de 11 anos. An Bras Dermatol. 2002;77:321-8.

44. Rippon JW. Dermatophytosis and dermatomycosis. In: Rippon JW. Medical Mycology - the pathogenic fungi and pathogenic actinomycetes. $3^{\text {rd }}$ ed. Philadelphia: Saunders; 1988. p. 169-275.

45. Rippon JW. Superficial infections. In: Rippon JW. Medical Mycology - the pathogenic fungi and pathogenic actinomycetes. $3^{\text {rd }}$ ed. Philadelphia: Saunders; 1988. p. 154-68,

46. Ruiz LRB, Zaitz C. Dermatófitos e dermatofitoses na cidade de São Paulo no período de agosto de 1996 a julho de 1998. An Bras Dermatol. 2001;76:391-401.

47. Santos JB, Negri CM, Wagner DC, Philip R, Nappi BP, Coelho MP. Some aspects of dermatophytoses seen at University Hospital in Florianópolis, Santa Catarina, Brazil. Rev Inst Med Trop Sao Paulo. 1997;39:137-41

48. Schoeler AP, Sguissardi CH, Bernardi E, Cembranel LR, Fuentefria AM. Prevalência de dermatófitos na rotina de Micologia em hospital particular de médio porte na cidade de Chapecó, estado de Santa Catarina, Brasil. Rev Ciênc Farm Básica Apl. 2010;31:103-6.

49. Sidrim JJC, Rocha MFG. Micologia médica à luz de autores contemporâneos. Rio de Janeiro: Guanabara Koogan; 2004. p.89-93.

50. Siqueira ER, Ferreira JC, Maffei CML, Candido RC. Ocorrência de dermatófitos em amostras de unhas, pés e mãos coletadas de estudantes universitários. Rev Soc Bras Med Trop. 2006;39:269-71.

51. Souza LKH, Fernandes OFL, Passos XS, Costa CR, Lemos JA, Silva MRR Epidemiological and mycological data of onychomycosis in Goiania, Brazil. Mycoses. 2010;53:68-71.

52. Wahab MA, Begum R, Hassan BS, Islam Z, Bhuiyan I, Khondker L. Tinea pedis: a clinica dilemma in Bangladeshi population. J Pakistan Assoc Dermatol. 2010;20:23-7.

53. Weitzmann I, Summerbell RC. The dermatophytes. Clin. Microbiol Rev. 1995;8:240-59.

54. Wille MP, Arantes TD, Silva JLM. Epidemiologia das dermatomicoses em população da periferia de Araraquara, SP. Rev Bras Clin Med. 2009;7:295-8.

55. Winston JA, Miller JL. Treatment of onychomycosis in diabetic patients. Clin Diabetes 2006;24:160-6.

56. Woodfolk JA. Allergy and dermatophytes. Clin Microbiol Rev. 2005;18:30-43.

57. Zaini F, Mahmoudi M, Mehbod ASA, Kordbacheh P, Safara M. Fungal nail infections in Tehran, Iran. Iranian J. Publ Health. 2009;38:46-53.

58. Zarrin M, Poosashkan M, Mahmoudabadi AZ, Mapar MA. Prevalence of superficial fungal infection in primary School Children in Ahvaz, Iran. Macedonian J Med Sci. 2011;4:89-92.

Received: 21 September 2010

Accepted: 28 November 2011 